\title{
AS RELAÇÕES ENTRE ESPAÇO COMO POTÊNCIA IMAGÉTICA E A CONSTRUÇÃO DE INDIVIDUALIDADES EM NATUREZA VIVA
}

THE RELATIONS BETWEEN SPACE AS IMAGINE POWER AND THE CONSTRUCTION OF INDIVIDUALITIES IN NATUREZA VIVA

LAS RELACIONES ENTRE ESPACIO COMO POTENCIA IMAGÉTICA YLA CONSTRUCCIÓN DE INDIVIDUALIDADES EN NATUREZA VIVA

Luiz Alberto dos Santos PAZ FILHO

\section{RESUMO}

O presente trabalho tem como objetivo investigar as relações entre a construção espacial e o desenvolvimento da subjetividade dos individuos poéticos em poemas da obra Natureza viva, de Walmir Ayala. Acredita-se que ambiente e individuo estejam diretamente conectados como processos linguísticos que configuram - discurso lírico do autor. Para compreender o desenvolvimento da produção lírica como discurso, buscouseinvestigar obras de referência como Conceitos fundamentais da poética, de Emil Staiger, A poética do espaço, de Gaston Bachelard, O arco e a lira, de Octavio Paz, dentre outras. Ao reconhecer os diversos âmbitos da produção artística do gênero lírico, pretendeu-se estabelecer um panorama da obra elencada com baseem uma lógica na qual o "eu" textual corresponde à extensãoda alma do ambiente em que se está inserido e/ou se almeja conceber.

PALAVRAS-CHAVE:

Sujeito poético; Espaço poético;

Poesia lírica.

\section{ABSTRACT}

The present work aims to investigate the relationships between spatial construction and the development of the subjectivity of poetic individuals in poems of the work Natureza viva, by Walmir Ayala. It is believed that environmentand individualare directly connected as linguistic processes that configure the lyrical discourse of the author. In order to understand the development of lyrical discursive production, reference works were sought as Conceitos fundamentais da poética, by Emil Staiger, A poética do espaço, by Gaston Bachelard, O arco e a lira, by Octavio Paz, among others. Recognizing the various spheres of artistic production of the lyrical genre, it was intended to establish a panorama of the work that is based on a logic in which the textual "me" corresponds to the soul extension of the environment in which it is inserted and / or sought to conceive.

\section{KEYWORDS:}

Poetic individual; Poetic space; Lyric poetry.

\section{RESUMEN}

El presente trabajo tiene como objetivo investigar las relaciones entre la construcción espacial y el desarrollo de la subjetividad de los individuos poéticos en poemas de la obra Natureza viva, de Walmir Ayala. Se cree que el ambiente y el individuo están directamente conectados como procesos linguísticos que configuran el discurso lírico del autor. Para comprender el desarrollo de la producción lírica como discurso, se buscó obras de referencia como conceptos fundamentales de la poética, de Emil Staiger, la poética del espacio, de Gastón Bachelard, El arco y la lira, de Octavio Paz, entre otras. Al reconocer los diversos ámbitos de la producción artística del género lírico, se pretendió establecer un panorama de la obra esbozada con base en una lógica en la que el "yo" textual corresponde a la extensión del alma del ambiente en el que está inserto y / o anhela concebir.

PALABRAS-LLAVE:

Sujeto poético; Espacio poético; Poesía lírica. 


\section{CONSIDERAÇÕES INICIAIS}

A construção de universos no campo da poesia lírica é rica por diversos motivos: Primeiro, porque o sujeito do poema é uma construção linguística - que não se confunde com a figura do narrador de textos narrativos, à medida que sua função e sua natureza são divergentes. A expressão lírica diz respeito a um sujeito discursivo autocentrado que traduz o mundo a partir de suas idiossincrasias, seus sentimentos e seus pensamentos. Não há narração de um passado reconstruído, mas sim de um eterno presente. Tal perspectiva leva diretamente ao segundo ponto a ser destacado: a temporalidade na produção lírica é singular: o eu poemático age como uma espécie de filtro para o mundo do agora. Existe a pré-concepção de um presente perpétuo, pois tudo o que é refletido e expresso em um poema nada mais é do que a tradução daquelas sensações no momento de sua própria produção.Desse modo, o leitor é responsável por atualizar o tempo presente no ato da leitura. Não se aprofunda a temática do passado, mesmo que os verbos queiram nos confundir em sua temporalidade porque não há distância espaço-temporal entre as ações e sua manifestação no texto poético. $\mathrm{O}$ agora é o tempo sempre ressignificado. Em A poética do espaço (1978), Gaston Bachelard afirma:

A imagem poética é uma emergência da linguagem, está sempre um pouco acima da linguagem significante. Ao viver os poemas tem-se pois a experiência salutar da emergência. Emergência sem dúvida de pequeno porte. Mas essas emergências se renovam; a poesia põe a linguagem em estado de emergência. A vida se mostra ai por sua vivacidade. Esses impulsos linguísticos que saem da linha ordinária da linguagem pragmática são miniaturas do impulso vital. (BACHELARD, 1978, p. 190)

A expressão destas emergências a que se refere Bachelard é constituída por diversos elementos que englobam todos os planos da linguagem: do morfológico ao semântico, passando pela sintaxe e pela fonologia. Assim, é preciso destacar outro ponto a respeita da criação de textos poéticos: sua apresentação em versos distribuídos em estrofes se dá de maneira orgânica e dinâmica, isto é, todos os planos linguísticos são construídos concomitantemente, assim como o falante da língua faz ao falar. $\mathrm{O}$ exercício racional da produção poética encaixa cada engrenagem da língua de forma a suscitar sentidos múltiplos, desde a escolha das formas e dos modos verbais ao uso de expressões no singular ou plural e repetições de sons vocálicos e/ou consonantais.

De acordo com Roman Ingarden, em A obra de arte literária (1973), "se toda a obra escrita é o espaço aberto e sempre disponível a uma infinidade de leituras diferentes, esta o é certamente de múltiplas maneiras." (INGARDEN, 1973, p.8) Assim, embora o ato produtor do texto literário seja realizado com objetivos específicos de causar determinados efeitos, o produto final e, portanto, as possíveis interpretações apreensíveis dele dependem do leitor. É nele que o ciclo da produção artística se conclui e se realiza, pois é no ato da leitura que os sentidos (e o tempo, conforme dito anteriormente) são vividos.

Se é no estágio da recepção que uma obra literária é ressignificada, faz-se necessário pontuar que o ato de sua leitura não é um processo simples e uniforme. Ao tratar de textos poéticos, não existe um manual ou guia que dê conta de explicitar de que forma e em qual ordem devem ser lidos os elementos constitutivos do texto. Ao elaborar esta pesquisa, serão seguidos alguns preceitos poéticos como base para as leituras aqui propostas. As concepções de poesia lírica que os autores citados constroem em seus discursos serão usadas como referencial. Ao utilizar esta noção, tem-se, por exemplo, partindo de Octavio Paz e Emil Staiger, a ideia de poesia como música (no sentido da importância sonora atribuída na construção do modo lírico). Logo, o plano rítmico dos poemas representará uma grande parcela semântica nas análises efetuadas. Além disso, ao se pensar na obra A poética do espaço (1978), de Gaston Bachelard, levar-se-á em consideração as construções imagéticas do texto como pontes entre o sujeito e as relações com o ambiente que o cerca, o qual idealiza ou deseja. Assim, se não é possível explicitar cada passo das análises poéticas, torna-se ao menos plausível indicar quais percursos estão sendo considerados.

Para a realização deste estudo, foram analisados quatro poemas de Walmir Ayala, com a finalidade de observar de que forma o sujeito se relaciona com o espaço e o que esta possível relação significa em seu universo literário. Walmir Ayala foi romancista, cronista, contista, poeta, crítico de literatura e das artes plásticas, e em sua vasta produção poética estabelece diferentes vínculos de seus eu-líricos com a natureza. Segundo José Castello, em sua coluna "Prosa \& Verso" do jornal O Globo, "poeta da terceira geração do Modernismo, Ayala é, muito mais que isso, um poeta inconfundível, que transforma a poesia em uma fracassada, mas bela, indagação sobre o oculto". (CASTELLO, 2011, p. 4)

A opinião elogiosa acerca do autor concorda com o jornal A cigarra, no qual em edição de 1966, na sua coluna sobre literatura, diz que "trabalhador infatigável, homem de talento e de sensibilidade, Walmir Ayala vem marcando a sua presença com uma forte atuação em quase todos os caminhos da nossa inteligência". (A CIGARRA, 1966 p. 14). Seu projeto de poesia lírica compreende quinze obras. Ao longo de suas obras, os eulíricos assumem diferentes relações com o mundo. A qualidade do conjunto literário de Ayala é inegável, não é à toa que ele tenha recebido tantos prêmios e nomeações, como o Prêmio Monteiro Lobato pela produção 15 infantil, III Prêmio Érico Veríssimo, Prêmio Olavo Bilac por Cantata, e diversos outros. Segundo Marco Lucchesi (2008) em edição dedicada a Walmir Ayala da coleção "melhores poemas", seria urgente organizar edições com reuniões de suas melhores obras poéticas. Ao falar sobre a produção lírica de Ayala, Lucchesi afirma que é "uma poesia-rio tributário de outras muitas, que se lança num delta complexo, a desaguar nos mais diversos aspectos e apelo". (LUCCHESI, 2008, p. 11)

\section{AS RELAÇÕES ENTRE ESPAÇO E SUJEITO}

Através de um processo subjetivo de seleção, foi elencada a obra Natureza viva (1973), de Ayala, para a realização do estudo. A obra em questão possui três subdivisões. Assim, optou-se por realizar a análise de um poema de cada uma das duas primeiras seções e de dois poemas 
da última parte. Fica, assim, o corpus de poemas para este ensaio: "Azul", pertencente à primeira subdivisão chamada de "Odes materiais"; o poema "A arca da aliança", em "As escrituras"; e os poemas "Atrás do jardim", e "Adivinhação" em "O país das maravilhas". A escolha dos textos buscou demonstrar a diferença de tons e percepções dos sujeitos poéticos ao longo da obra, de modo a construir uma unidade global.

Para iniciar o estudo, em "Odes materiais", vamos ao poema "Azul":

\section{O azul é haver atrás do céu. É ver-se \\ O azul e se pensar no céu, $e$ haver}

Denso pássaro abrindo o céu e o azul

A escorrer, a escorrer.

O azul é o além do gesto, éo

De uma rosa envolvente, azul e vasta

E única e final: rara e invisivel

Pauta de eternidade, e haver na

forma

Desta rosa sem forma a

claridade.

$O$ azul é a forma com que as folhas pairam

Na noite umbrosa, e o pó que as envelhece

Em paz. É estar passando

Um homem e sumir-se, e ter passado

Um homem sem figura em nossa morte.

O azul é olhar: onde estarão as urnas

Dos mortos? Onde as asas desses muitos

Que os lábios da saudade chamam almas?

(p. 221)

Através de uma espécie de psicologia das cores, o poema citado constrói cenários e sensações a partir de uma provocação sinestésica. A cor azul se transforma, metonimicamente, no céu, na liberdade,

1 Todos os poemas utilizados neste estudo estão

presentes na obra Natureza viva, da editora

Cátedra, de 1973 na vastidão, no mistério e em outras características determinadas pelo olhar do sujeito poético ao texto. A configuração do azul, título do poema, se dá de forma gradual. $\mathrm{O}$ eu-lírico introduz sua primeira percepção acerca da cor na forma de uma sentença curta e objetiva: "O azul é haver atrás o céu”. Apresentado como uma espécie de escudo translúcido capaz de resguardar a infinitude do céu, o azul se condensa, mas não se limita. Ainda na primeira estrofe, o sujeito poético observa: "e haver / denso pássaro abrindo o céu e o azul / a escorrer, a escorrer". Com esta enunciação, cria-se a imagem de um pássaro que cruza toda a imensidão do céu azul, como se ele pudesse representar um sentimento penetrante na imensurável consciência humana. Ao abrir o céu, o pássaro permite que outras sensações alegoricamente "escorram" da percepção de mundo do eu-lírico.

Nota-se a repetição das palavras "céu", "azul", "haver" e "escorrer", respectivamente dois substantivos e dois verbos, ao longo da primeira estrofe. Ao reforçar tais expressões, o sujeito textual está intensificando a importância da imagem do céu e da cor azul, por meio de uma relação mútua entre os dois signos, a qual faz nascer um novo universo de significados no poema. Os verbos no infinitivo podem sinalizar uma extensão impessoal da semântica das palavras, universalizando a capacidade dos sentimentos em cada indivíduo. Por outro lado, ainda em relação aos verbos, é possível identificar a assonância da vogal /e/ fechada que ecoa em outras palavras dos quatro versos da estrofe, como "ver" e "se", estabelecendo, assim, um clima sólido sem quebras drásticas no plano fônico. Segundo Emil Staiger, em Conceitos fundamentais da poética (1977),

nem somente a música das palavras, nem somente sua significação perfazem o milagre da lírica, mas sim ambos unidos em um. Não podemos todavia criticar, se alguém se abandona mais ao efeito imediato da música; pois mesmo o poeta sentese quase inclinado a dedicar uma certa primazia à parte musical, $e$, desvia-se, por vezes, das regras e usos da linguagem determinados pelo sentido, a bem do tom ou da rima. (STAIGER, 1977, p. 8)
Muito mais poderia se dizer a respeito dos efeitos musicais do poema, contudo, destaca-se aqui sua significação como formade incitar em outros leitores uma maior dedicação a este objeto apreensível de significações no estudo da lírica. Os efeitos rítmicos provocados pela construção sonora de um poema não são artifícios acrescentados ao poema como mera espécie de edição textual, pelo contrário: som, palavra e verso são construções concomitantes. O ritmo é inato à palavra. Essas provocações poderão ser desenvolvidas com maior profundidade em pesquisas futuras.

Após captar o sentido da visão, no início do poema, o azul amplia seu campo sinestésico ao tornar-se uma possível matéria sólida. No primeiro verso da segunda estrofe, o sujeito poético diz: "O azul é o além do gesto", apontando para uma manifestação que vai além do movimento físico de um indivíduo, e continua, completando no segundo verso: "é o sangue / de uma rosa envolvente". Nota-se o jogo linguístico da palavra "rosa", que simboliza tanto a flor do amor quanto a própria cor que está associada ao romance. Assim, o caráter mutável do azul parece pintar uma paisagem adaptável ao estado de espírito de cada ser. No final desta estrofe, o eu-lírico revela ainda que esta rosa é sem forma, mas guarda a claridade, desse modo, novamente ocorre um jogo de sentidos, visto que é o azul uma das principais cores que simbolizam a claridade e a harmonia. Vale lembrar que a captação de tais sentimentos se dá de maneira particular, afinal, estas percepções são fundamentais na ideia de Ingarden sobre o texto artístico, uma vez que o autor ressalta que "o conteúdo da poesia é, portanto, aquilo que "o poeta viveu no momento da criação e que reviverá em nós durante a percepção da obra (o "conteúdo" reconstruido)." (INGARDEN, 1973, p. 28)

Ao iniciar a terceira estrofe do poema, o sujeito poemático revela que "o azul é a forma com que as folhas pairam / na noite umbrosa". Ou seja: o azul toma a forma de um material tipicamente verde da natureza, a folha, e paira em destaque na noite escura, fato que lhe proporciona atributos de claridade. Ao mesmo tempo em que cria esta imagem relacionada à natureza-viva do mundo, o eu-lírico a vincula, a seguir, ao próprio ciclo da vida humana ao dizer: "é estar passando 
/ um homem e sumir-se, e ter passado / um homem sem figura em nossa morte". Isto é, a imensidão dos mistérios do azul é capaz de resgatar a memória de quem partiu, seja de uma folha que paira no escuro ou de um indivíduo que tem sua morte decretada.

Ao transgredir o sentido inicial de um tom da natureza iminente, o azul assume camadas mais profundas que reconfiguram o imaginário do sujeito poético, levando-o a refletir sobre gostos, toques e formas de ver a vida e a morte. Sobre este último aspecto, há o reforço de tal hipótese na quarta estrofe ao afirmar "o azul é olhar" - um retorno à sua posição inicial de espectador do mundo, sob a hipnose da vastidão azul do céu. $\mathrm{E}$ ao encerrar o poema com duas perguntas ("onde estarão as urnas / dos mortos? Onde as asas desses muitos / que os lábios da saudade chamam almas?") o eu-lírico retoma o mito da alma humana como essência da razão de ser humano. Não é à toa que o azul simboliza também, segundo a psicologia, o infinito: porque é o encontro do céu com o mar, no horizonte, que fecunda a crença de que tudo durará o tempo da eternidade até que sejamos capazes de alcançar o final deste azul.

Para dar continuidade ao estudo, olhemos para o poema "A arca da aliança", em "As escrituras":

Submersa no antigo testamento Palpita a arca da aliança.

Seus sinais assomam na curva do arco-íris:

Todo laivo de amor tem a luz de seus metais;

O suspiro da morte é lancinante como o seu silêncio

Ante o qual os anjos dobram os mirificos joelhos.

É a única verdade da História que ninguém sabe situar, Que ninguém viu o fim, mas que ficou perdida

Entre guerras antigas

Quando o assalto dos corpos era a aventura generosa,

Quando a lâmina embainhada em sangue era a chave do gesto

E os corações contendores

estavam mais próximos

Que as páginas de um livro.
Há quem procure a arca da
aliança:

Em certas noites doloridas é a surpresa de uma voz,

A rosa de uma confissão, a

certeza de um canto.

Há quem diga: "Hoje eu sei onde está

A arca da aliança" - o ouro da margem de um rio

Estelar vai pousar nesta boca,

E queima, com certeza, como

algum sacrilégio.

Caem os véus do templo, rasgamse os pálios, rompem

As tábuas apagadas da lei no sonho de Moisés.

E o dono do vislumbre da arca da aliança,

Nu e transpassado

Atravessa em silêncio os andaimes da morte.

Walmir Ayala é um poeta de tradição católica. As influências do Cristianismo em sua vida aparecem, não raro, em suas obras. No poema transcrito, "A arca da aliança" as simbologias cristãs aparecem para compor o quadro textual do poema e inferir novos signos dentro do imaginário popular por meio de seu sujeito poético.

Segundo a mitologia cristã, a Arca da aliança é uma espécie de baú feito de ouro, que fica localizado no templo de Salomão. Dentro deste baú estariam algumas das principais relíquias do Cristianismo, como a Tábua dos Dez Mandamentos. De acordo com textos bíblicos, somente os puros sacerdotes poderiam tocá-la, caso contrário a morte era o destino selado imediatamente.

A partir de tais preceitos é possível identificar algumas pistas e referências apresentadas pelo eu-lírico do poema, que intenta reconstruir os significados santificados desta arca de forma a revitalizar a simbologia de esperança, pureza e poder a ela vinculados. É interessante destacar a famosa conclusão de Staiger, em Conceitos fundamentais da poética (1977), quando o autor afirma que "o passado como objeto de narração pertence à memória. $\mathrm{O}$ passado como temática do poema lírico é um tesouro de recordação". (STAIGER, 1977, p.26) Ao tratar de um tema que lida diretamente com crenças religiosas, a ideia de mitologia acerca dessa fé, conforme dito anteriormente, é suscitada.

Nos dois primeiros versos do poema é possível observar o caráter pungente e vivo atribuído ao objeto, uma vez que ele "palpita" como um coração, no templo. É interessante notar a possibilidade de a palavra templo ter sido utilizada de forma ambígua: ao passo que ela pode sinalizar, de fato, o templo concreto onde a arca esteja enterrada, segundo as histórias bíblicas, mas também pode indicar um signo geral que representa um indivíduo, associando-o a uma espécie de fortaleza, um local sagrado que deve ser cuidado. Afinal, não estaria submerso em cada um de nós a chave que permite acesso aos nossos maiores segredos e tesouros?

$\mathrm{Na}$ segunda estrofe, ao desenvolver a ideia sacra da arca, o eu-lírico informa que os anjos ajoelham-se perante ela e a morte é silenciosa em sua presença. A aura misteriosa é facilmente relacionável aos segredos e às possíveis interpretações dos textos bíblicos que narram o Cristianismo. Embora a morte ronde seus contos, o laivo de amor e o arco-íris parecem coexistir. Seria o embate entre Bem e Mal o maior segredo da humanidade? $\mathrm{Na}$ terceira estrofe, o sujeito lírico segue declamando o rumo misterioso e seu paradeiro incerto, narrando seu destino em meio às guerras históricas e aos confrontos humanos. Observa-se o caráter quase híbrido do poema, no qual o lirismo do gênero poético encontra-se com a narratividade.

É na quarta estrofe que novos elementos surgem, no entanto, é preciso relacionar esta passagem à ideia levantada no início desta análise sobre o templo significar o próprio indivíduo. Segue-se: "Há quem procure a arca da aliança: / em certas noites doloridas é a surpresa de uma voz, / a rosa de uma confissão, a certeza de um canto.” E se, talvez, a arca não existisse como objeto material, mas fosse uma ideia, uma crença? Após o questionamento, cabe citar Bachelard que afirma:

A exuberância e a profundidade de um poema são sempre fenômenos da dupla: ressonânciarepercussão. Parece que, por sua exuberância, o poema desperta profundezas em nós. Para nos darmos conta da ação psicológica de um poema, teremos pois de 
seguir duas linhas de análise fenomenológica: uma que leva às exuberâncias do espirito, outra que vai às profundezas da alma. (BACHELARD, 1978, p. 187)

Dessa forma, basta a fé exigida pelo Cristianismo para encontrá-la - porque, no final das contas, ela é uma essência daqueles que creem. Afinal, como assume o próprio sujeito poético, "Há quem diga: hoje eu sei onde está / a arca da aliança". Este sacrilégio parece vir ao encontro da teoria na qual a santidade está na pureza das intenções, na bondade.

Na quinta estrofe, o eu-lírico enfatiza, dentre outros aspectos: "caem os véus do templo [...] / e o dono do vislumbre da arca da aliança, / nu e transpassado / atravessa em silêncio os andaimes da morte. Não seria necessário, em última análise, o despir-se do mundano e a proximidade à fé para que se encontrasse a arca? Ficaria, evidentemente, a questão: o que há dentro dela? Mas a resposta, segundo o sujeito poemático, não pode ser ecoada, pois é preciso o silêncio da morte, o silêncio da sabedoria de quem alcançou o estágio mais puro de si para compreender a mensagem última.

Por meio da arca da aliança, item advindo da mitologia cristã, o eu do poema parece processar as ideias de fé e identidade na criação de uma paisagem humana: lê-se paisagem como um comportamento, um quadro pintado em sua crua representação. Afinal, a ideia de uma topoanálise literária só pode ser concebida a partir da construção discursiva dos sujeitos poéticos. É através da construção dos discursos deste sujeito textual que noções de sujeito e espaço podem se revelar. No poema analisado é possível associar indivíduo e espaço como uma mescla da retomada da história da fé, na qual o plano de fundo das crenças cristãs contribui para a construção de uma identidade social. Os modos de ver o mundo traduzidos pelo sujeito poético revelam, ao mesmo tempo, uma paisagem observada. Como é este mundo? É um espaço de esperança e de conflito - porque embora haja noções de Bem e Mal, que são uma dualidade externa, há um choque interno em cada sujeito, uma incerteza enfrentada diariamente com a esperança de que um dia os véus caiam e as respostas sejam encontradas.

Observe-se, então, na última subdivisão da obra de Ayala,"o país das maravilhas", o poema "Atrás do jardim":

Atrás do jardim, onde as goiabas e as jaboticabas dormem ao ópio do verão, ali pastam cavalos lentos sobre floradas de paina.

Com que doçura a claridade Alinha a transparente toalha De sua mesa.

Até o lixo

Tem um momento de leveza

E se deixa cobrir de flor

E silêncio.

Uma fonte apenas se debulha Regendo um instante de moscas Que buscam o cristal do dia.

\section{Mover-se era uma forma do eterno \\ Estar pelo avesso. Logo}

Perdíamos a rosa dos ventos.

$$
\text { (p. 93) }
$$

Uma das marcas dos poetas modernos, segundo Hugo Friedrich, em Estrutura da lírica moderna (1978), é o uso do cotidiano e de tudo o que soava como "antipoético" em sua produção literária. No poema transcrito de Walmir Ayala, o sujeito poético assume uma posição de espectador do mundo para filmar uma cena que poderia ser considerada banal. Ao pintar um quadro que transborda tranquilidade por conter elementos visuais como um jardim, cavalos pastando e uma toalha transparente de mesa, o mundo parece pairar sobre a imagem de uma paisagem esquecida. Ao construir uma visão desse mundo - que, como veremos, sofre uma pesada alteração na segunda metade do poema - o sujeito poético parece refletir um estado pessoal de alma. Poderia esta individualidade causar um impacto empático de maior escala?

Na primeira estrofe do poema, o eu-lírico abre o primeiro verso repetindo o título do texto, que, na verdade, ambientaliza o seu universo poemático: "Atrás do jardim, onde as goiabas / e as jaboticabas dormem / ao ópio do verão [...]". Notase o detalhamento deste jardim: há nele goiabas e jaboticabas, o que indica uma espécie de nostalgia deste sujeito do poema, como se ele estivesse descrevendo um cenário íntimo. Não se trata de um jardim qualquer, pois ele já sabe que nele os cavalos pastam lentamente e as árvores dormem sob o sol forte do verão. A imagem da paina corrobora à construção de um cenário bucólico e harmônico. Não há nada neste jardim que incite qualquer dúvida ou frustração - poderia ser um reflexo do sujeito que o descreve? Conforme Octavio Paz, em O arco e a lira (1982),

Com efeito, a poesia é desejo. Mas esse desejo não se articula no possivel nem no verossimil. A imagem não é o "impossivel verossimil", desejo de impossiveis: a poesia é fome de realidade. $O$ desejo aspira sempre a suprimir as distancias, conforme vemos no desejo por excelência o impulso amoroso. A imagem é a ponte que liga o desejo entre $o$ homem e a realidade. (PAZ, 1982, p. 80)

Assim, é possível dizer que as imagens construídas pelo discurso do sujeito poético são possibilidades desejantes. No poema transcrito, a imagem do jardim parece abrir, no mínimo, dois caminhos de leitura: em um deles, o reconhecimento deste local é um espelhamento dos próprios intuitos do eu-lírico; por outro lado, seria possível compreender esta ambientação como um retorno deste indivíduo às origens de suas experiências. Dentre outras possibilidades de interpretação, parece imprescindível enfatizar a força imagética em construções de fácil acesso. No poema em questão, não há grandes efeitos paradoxais ou metafóricos, conforme será analisado. Continuemos a leitura.

Na segunda estrofe do texto, outro detalhe é acrescido: há uma mesa neste jardim, cuja toalha transparente recebe atenção especial do eu-lírico. Teria ele realizado piqueniques neste jardim? Seria a toalha transparente da mesa um signo que o leve a uma viagem ao passado? Estaria ele em um sítio da infância, em um local de segurança espiritual? Ou estaria ele apenas brincando com nossas expectativas, sendo, assim como nós, um recém chegado nessa espécie de paraíso? Há uma doçura que alinha a mesa, o jardim e seu universo. Conforme descrito na terceira estrofe, "até o lixo / tem um momento de leveza / e se deixa cobrir de flor / e silêncio". Assim, 
até o mais mundano e sujo perde força perante este ambiente florido e calmo. Em certo nível, este local aproxima-se da representação mais simplória do Paraíso descrito na Bíblia cristã.

Nada parece romper com o silêncio e paz de sua contemplação. Uma fonte ameaça quebrar o encanto, mas são apenas moscas que, perdidas, vagueiam pelo infinito pastoril. Na última estrofe do poema, a revelação: "mover-se era uma forma do eterno / estar pelo avesso". O tempo e o espaço estabeleceram um outro tipo de diálogo. É possível identificar a quebra dos paradigmas da física. O que mantém este mundo intacto é a estática, a ausência de ação. $\mathrm{O}$ menor gesto seria capaz de perturbar a natureza desta paz. "Logo / perdíamos a rosa dos ventos", explica o eu-lírico no último verso. Talvez a incapacidade de manter a contemplação e a mente livre dos pecados e obscuridade dos atos humanos fizesse a rosa despetalarse no vento. Mas o medo da instauração de um caos é detido. Não há demonstração da instabilidade. Algo parece fazer com que suas preocupações sejam contidas. Lembremos do " $4^{\circ}$ motivo da rosa", de Cecília Meireles: "Não te aflijas com a pétala que voa / também é ser deixar de ser assim" (MEIRELLES, 2000, p. 78). Afinal, ao mover-se, o infinito torna-se passageiro.

A esta altura parece importante esclarecer uma questão que diz respeito ao ato produtor da poesia. Por muito tempo, acreditou-se que o poeta recebia uma dádiva divina na forma de inspiração para escrever. Assim, seus poemas seriam uma forma de revelação quase instintiva. Já no mundo moderno, a cientificidade e o método para a produção receberam atenção e o artista passa a ser humanizado. Segundo Hugo Friedrich, em Estrutura da lírica moderna (1978),

o conceito de estado de ânimo indica distensão, mediante o recolhimento, em um espaço anímico, que mesmo o homem mais solitário compartilha com todos aqueles que conseguem sentir. É justamente esta intimidade comunicativa que a poesia moderna evita. (o eu pessoal do poeta) não mais participa em sua criação como pessoa particular, porém como inteligência que poetiza, como operador da língua, como artista que experimenta os atos de transformação de sua fantasia imperiosa ou de seu modo irreal de ver num assunto qualquer. (FRIEDRICH, 1978, p. 17)

Pretende-se, com tal interpelação, justificar a mudança brusca de sentidos e representações criados em cada poema do autor. Em cada obra textual, há uma construção ulterior de um sujeito do discurso. É este sujeito que criará vínculos, sentimentos, pensamentos e atitudes que possibilitarão a expressão no poema. Por isso, em cada momento da uma obra maior, o eu-lírico é único, pois expressa uma distensão anímica que o leva a refletir sobre determinados assuntos e sensações e, por conseguinte, a expressá-los em formas, sentidos e linguagens distintas.

Ainda na última subdivisão proposta na obra de Ayala, temos o poema "Adivinhação":

\section{Se fosse água seria abismo \\ Com lentas e exatas geometrias \\ Desenhadas pelas areias;}

Se fosse cor seria forte

Como o cristal que se transpassa

Com leves céus de azul no fundo;

Se fosse música, sonata

De clavicórdio - Bach - distância

De pássaro que nunca volta;

Se fosse gesto, claro grito

Com feixes de luz pelos quatro

Cantos irreais da vida;

Se fosse flor, desenho exato

De caprichoso labirinto

Com todas as chaves expostas;

Se fosse verde - uma floresta

Onde eu passasse, onde eu

passasse,

Sem medo nenhum, como aquelas Nuvens que passam sem dano

Pela estrada do sonho humano,

Se fosse um bicho, corpo certo

Forrado de plumas e ásperas

Centelhas de dourado pólem,

Mas severo como a engrenagem

De um animal que ainda se fosse

Criar: um santo por imagem.

(p. 104-105)
O poema transcrito estabelece o desenvolvimento da identidade através do olhar apurado da alteridade, em um sistema dicotômico que fica subentendido pela comparação do eu-lírico com um outro observado e por ele analisado. $\mathrm{O}$ título é emblemático: adivinhação. $\mathrm{O}$ modo expressivo do sujeito poético parece tentar adivinhar as características sobre "um outro", partindo de formações frasais afirmativas, como se não houvesse dúvida em tais palpites. $\mathrm{O}$ outro construído discursivamente pela leitura de mundo do eu poemático é revestido de características positivas. Tais adjetivações, no entanto, criam uma imagem quase santificada, como se natureza e sujeito fossem capazes de se transmutar para conceber um único indivíduo.

Através da anáfora dos primeiros versos de cada estrofe, há um discurso permeado pelo modo subjuntivo, que apresenta hipóteses sobre um indivíduo imaginado ou observado pelo eu do poema. A expressão "se fosse" abre seis das sete estrofes do poema, e, em cada caso, introduz uma situação na qual o outro forma uma simbiose com elementos do ambiente e da natureza, a fim de estabelecer um padrão que revela sua potência semântica em sintagmas ressignificados. A respeita de tal fenômeno, parece importante trazer à discussão novamente a obra de Octavio Paz, O arco e a lira (1982), na qual o autor afirma:

a linguagem é significado: sentido disto ou daquilo. As plumas são leves; as pedras, pesadas. O leve é leve em relação ao pesado, o escuro diante do luminoso, etc. todos os sistemas de comunicação vivem no mundo das referências e dos significados relativos. Dai que sejam conjuntos de signos dotados de certa mobilidade. Por exemplo, no caso dos números, um zero à esquerda não é o mesmo que um zero à direita: as cifras modificam seu significado de acordo com sua posição. Outro tanto ocorre com a linguagem, só que sua gama de mobilidade é muito superior às de outros processos de significação e comunicação. (PAZ, 1982, p. 129)

Assim, questiona-se sobre a função da linguagem nas construções imagéticas do poema. Embora cada palavra tenha em si um sentido "dado", é somente em 
seu exercício ativo no presente que esta significação se efetuará ou não. No caso do texto literário, é comum que o sentido "ordinário" da palavra seja substituído por um novo, devido ao contexto o qual a palavra é empregada. No poema, sobretudo, uma expressão terá um significado único, pois se encontra em uma construção discursiva que pretende, dentre outros efeitos, provocar, insinuar e simbolizar, mais do que dizer abertamente.

$\mathrm{Na}$ primeira estrofe, a exatidão e profundidade das águas em queda apontam para um comportamento sinuoso e elegante, no qual os movimentos deste outro analisado e imaginado são realizados com perfeição e cada gesto seu possui um significado consciente. Suas ações levam a consequências necessárias, como o desenho nas areias; na segunda estrofe, sua coloração se confunde com o brilho translúcido do cristal, que revela a potência multifacetada de seus gestos que, em última análise, refletem o azul do céu (poderíamos remeter este poema ao anteriormente analisado "Azul"?); na terceira estrofe, o elemento sonoro cria uma atmosfera de plenitude, na qual a comparação com uma sonata de Bach é evocada para construir a imagem de um voo sem retorno de pássaro. O clavicórdio suscita um elogio às artes clássicas desde, pelo menos, a Idade Média. $\mathrm{O}$ instrumento musical apresenta uma sonoridade suave que ajuda a manter a harmonia da cena até então evocada pelo sujeito poético; na quarta estrofe, há uma espécie de jogo de sentidos, onde elementos sinestésicos têm suas funções alternadas entre si: o grito possui cor clara, e não som, e mais do que isso, apresenta feixes de luz, como se a voz do outro pudesse iluminar os confins da alma.

Ao compará-lo, no entanto, com uma flor, seus labirintos pintados em pétalas teriam exposto as chaves como guias para sentir seu aroma, apreciar sua cor e respeitar sua história - porque a natureza e o homem parecem precisar de uma reaproximação transcendental; na quinta estrofe, há a continuidade da construção simbólica da natureza através de árvores relacionadas à cor verde. Neste caso, o desejo é de permanência, de apaziguamento e de esperança. "Uma floresta / onde eu passasse, onde eu passasse, / sem medo nenhum, como aquelas / nuvens que passam sem dano / pela estrada do sonho humano", diz o sujeito poético. Nota- se o poder da flora como algo capaz de suspender a condição de humanidade, elevando o sonhoao patamar de um ambiente pacífico e acolhedor. É importante ressaltar o que foi dito no início desta interpretação: o título é conveniente, pois o processo de adivinhação não exige qualquer formalidade estética ou racional.

\section{CONSIDERAÇÕES FINAIS}

Todas essas possibilidades de ser, elencadas pelo eu-lírico, parecem revelar um desejo e uma idealização de um estilo de vida, no qual o homem e a natureza estabelecem uma conexão vital. Mesmo que essas engrenagens sejam suscetíveis à falha, o sujeito seria capaz de recriar um universo de maravilhas, pois o ambiente dar-lhe-ia poder para tal. Embora nem sempre sejam estabelecidas imagens explícitas da conexão entre indivíduo e ambiente, tem-se de antemão a ideia de que nenhuma criatura vive sem considerar seu local, afinal, toda produção humana é influenciada em maior ou menor nível pelas experiências singulares que escrevem a jornada de sua vida. Dessa forma, é possível também afirmar que os deslocamentos realizados pelos sujeitos ao longo de sua vida influenciam nas tomadas de decisões, desejos, gostos e também desgostos. As imagens préestabelecidas sobre lugares, cheiros e sabores são confrontadas quando se tem a oportunidade de experenciá-las no plano da realidade. Assim, aquele local sonhado, os gostos imaginados de uma torta, os cheiros das flores que brotam no parque podem ou não corresponder àquela concepção que se tinha apenas no plano interno.

Ao seguir as perspectivas aqui elencadas, levanta-se a hipótese de que o espaço, sob o signo da natureza, parece ter um papel fundamental na produção poética de Walmir Ayala, sobretudo na obra selecionada Natureza viva. Tanto no que diz respeito à consciência e ao questionamento em relação ao espaço que ocupa quanto no tocante à condição de experiência particular que pode assumir, $o$ indivíduo poético parece funcionar como uma espécie de criatura consciente, frente à potência influenciadora do ambiente que o cerca. Interessa, portanto, investigar os desdobramentos de questões oriundas do par espaço-tempo em consonância ao aspecto identitário que ele implica, mas, essencialmente e, sobretudo, em relação ao fator estético desenvolvido ao longo do projeto artístico lírico do autor.

No âmbito da análise dos poemas é importante ressaltar que outros textos da mesma obra poderiam ser revisitados partindo da ótica aqui introduzida, e o que foi apresentado partiu de uma seleção prévia. Diversos podem ser os caminhos desenvolvidos pelos pesquisadores na leitura da poesia de Ayala. $\mathrm{Na}$ obra em questão, Natureza viva, as questões identitárias parecem corresponder a um duplo processo de reconhecimento: em primeira instância, diz respeito a um procedimento interno, uma reflexão sobre si mesmo; depois, mas não em segundo plano, estariam os desdobramentos que o ambiente tem ao longo das esferas da consciência, da memória e da concepção de mundo que aquele eu-lírico apresenta. Diz-se que o ambiente não se encontra posterior ao pensamento de si, porque, conforme se pretendeu expor, não há uma hierarquização quando se trata de indivíduo e mundo. Há, talvez, uma série de combinações que podem vir a resultar em múltiplas perspectivas que retumbam, por fim, no modo de ser e de viver dos sujeitos poéticos.

Assume-se a consciência de fatores que não foram devidamente aprofundados ao longo deste breve estudo, como a influência do tempo na concepção de espaço e/ou noções problematizadoras de consciência individual. Além disso, caberia ainda pensar em outros estímulos externos que contribuem para a cristalização de ideias sobre seres e lugares. Os fatores que agem no subconsciente também devem afetar de alguma forma as relações a serem mantidas ou esquecidas no interior de cada sujeito. No entanto, devido à natureza breve deste ensaio, pretendeu-se explanar de forma panorâmica determinadas questões, mantendo a esperança de que estas e outras venham a ser examinadas com maior cuidado no futuro, ao passo que ficam também como sugestões para eventuais leitores da poesia brasileira.

\section{REFERÊNCIAS}

AYALA, Walmir. Natureza viva. Rio de Janeiro: Cátedra, 1973.

BACHELARD, Gaston. A poética do espaço. Tradução de Antônio da Costa Leal e Lidia do Valle Santos Leal. São 
Paulo: Abril Cultural, 1978

CAstello, josé. Prosa e Verso. O Globo. 30 de julho de 2011. Disponivel em: < http://lemetro.ifcs.ufrj.br/ resenha_nas_trilhas_da_amazonia. pdf $>$ Acesso em 28.08.2018

FRIEDRICH, Hugo. Estrutura da lírica moderna: da metade do século XIX a meados do século XX. Trad. Marise M. Curioni. São Paulo: Duas cidades, 1978.
INGARDEN, Roman. A obra de arte literária Lisboa: Louste Gulbenkian. 1973

LUCCHESI, Mario. Walmir Ayala: seleção. São Paulo: Global, 2008

MEIRELLES, Cecilia. Melhores poemas. 12ª ed. São Paulo: Global, 2000.

PAZ, Octavio. O arco e a lira. Trad. Olga Savary. Rio de Janeiro: Editora Nova Fronteira, 1982.

\section{STAIGER, Emil. Conceitos fundamentais da poética. Rio de Janeiro: Tempo brasileiro, 1977.}

Walmir Ayala: mais poesia. A Cigarra. Ano 52, n9, setembro de 1966. Disponivel em: <http://200.144.6.120/ uploads/acervo/periodicos/jornais/ cl19660909.pdf> Acesso em 1ㅇ Setembro de 2018.

\section{Recebido em 16 Mar 2019 ～Aprovado em 12 Jun 2019}

Luís Alberto dos Santos PAZ FILHO

Doutorando em Teoria da Literatura (bolsista Capes) pelo Programa de Pós-Graduação em Letras da Pontificia Universidade Católica do Rio Grande do Sul, tendo adquirido a titulação de Mestre em Teoria da Literatura pelo mesmo Programa no ano de 2019. Sua formação inicial é na Graduação no Curso de Licenciatura em Letras, da mesma Universidade, onde atuou como Bolsista de Iniciação Cientifica no periodo de 2013 a 2017 , em projetos voltados para a área dos estudos literários. E-mail: Luis.alberto@acad.pucrs.br 